\title{
Cloning of Presenilin 2 cDNA and Construction of Vectors Carrying Effective Mutations in the Pathogenesis of Familial Alzheimer's Disease
}

\author{
Gözde Öztan ${ }^{1}$ (D) Baki Yokeş² ${ }^{(D)}$, Halim İşsever ${ }^{1}$ \\ 'Department of Public Health, İstanbul University School of Medicine-Çapa, İstanbul, Turkey \\ ${ }^{2}$ AMBRD Laboratories, İstanbul, Turkey
}

Cite this article as: G. Öztan, B. Yokeş, H. İşever, "Cloning of Presenilin 2 cDNA and Construction of Vectors Carrying Effective Mutations in the Pathogenesis of Familial Alzheimer's Disease", Electrica, vol. 18, no: 2, pp. 310-320, 2018.

\section{ABSTRACT}

Alzheimer's disease (AD) is a neurodegenerative disease and is identified by the detection of amyloid-plaques and neurofibrillary tangles in the brain. Amyloid precursor protein gene, presenilin 1 (PSEN1) gene, and presenilin 2 (PSEN2) gene are responsible for this disease. PSEN2 and amyloid precursor protein (APP) gene mutations are a much rarer cause of familial AD patients. This study aims to clone the PSEN2 gene and create vectors with different mutations by directed mutagenesis. As a result of the experiments, the PSEN2 cDNA was cloned between the BamHI and Kpnl cut-off points of the pBluescript II sk (+) vector. PSEN1 and PSEN2 homologs have a role in cell destiny decision and AD progress. We studied some of the PSEN2 mutations (Ala252Thr and Pro334Arg) and provided expression analysis in eukaryotic cell cultures. Amyloid $\beta$-protein (A $\beta$ ), which is produced by endoproteolytic cleavage of the APP, is considered to play a role in AD. While nominal concentration of A 440 is 10 times of $A \beta 42$, the last peptide is firmly linked to $A D$ pathogenesis. Amyloid $\beta$-protein is generated by the $\gamma$-secretase cleavage of APP onset and the progression of AD, and it is the primary ingredient of the senile plaques. The A 42 dodecamer plays a central role in AD. In future studies, it will be determined if there is an increase in A 42 protein levels, and the effect on this early onset $A D$ can be identified.

Keywords: Alzheimer's disease, presenilin 2 gene, $A \beta$, pathogenesis, $X L-1$ Blue

\section{Corresponding Author: \\ Gözde Öztan}

\section{E-mail:}

gozdeoztan@yahoo.com

Received: 02.04.2018

Accepted: 17.05 .2018

(c) Copyright 2018 by Electrica

Available online at

http://electrica.istanbul.edu.tr

DOI: 10.26650/electrica.2018.12050

\section{Introduction}

\section{Alzheimer's Disease}

Alzheimer's disease is a common neurodegenerative disease, and the elderly make up more than $80 \%$ of the world's dementia cases. It leads to the gradual decline of mental, behavioral, functional regression and learning ability. Two hundred thousand people with AD under sixty-five years old constitute the younger onset $A D$ population; five million are sixty-five years old or older [1].

Two pathological lesions called abnormal plaques and neurofibrillary tangles (NFT) are suspected of scathing neuronal cells and are identified as the principal pathologic markers of AD. Senile plaques are identified $A \beta 42$ and $A \beta 40$ peptides. Brain amyloidosis is consist of accumulation in spaces among neural cells. $A \beta$ peptides are effective in impairing the survival of nerve cells and it is the most important reason for the emergence of AD. Neurofibrillary tangles are spun fibres of tau protein in cells [2].

Alzheimer's disease is most often associated with episodic memory impairment and language deficiency, visual abilities and functional disorders that occur in the course of the disease. Alzheimer's disease is not "normal" or an expected occurrence of aging [3].

$A D$ is identified by the accumulation of paired helical fibers formed by abnormal tau proteins and deposits of $A \beta$ plaques. These plaques are include $A P O E$, heparan sulfate proteoglycans, and a-antichymotrypsin [4]. The dementia is caused by synaptic damage subsequent to neu- 
ronal loss. This damage is caused by microglial cell reproduction, astrogliosis and neurofibrillary tangles [5].

Alzheimer's disease pathogenesis involves the advancing accumulation of amyloid- $\beta$ protein. This abnormal accumulation is the consequence of an instability between the levels of $A \beta$ production, clearance, and aggregation [5].

Alzheimer's disease is a multifactorial disease, and Alzheimer's disease progression is related to a few alterable and unalterable risk factors. Age is the most important risk factor for the progress of Alzheimer's disease. The probability of progressive Alzheimer's disease rises exponentially with age. The vast majority of individuals suffering from $A D$ are aged 65 or older and have 'late-onset' or 'sporadic' AD (> 95\% of all cases). Rare genetic mutations are associated with the development of $A D$ before age 65, which is known as 'early-onset' or 'familial' AD (< $5 \%$ of all cases).

Apolipoprotein $\mathrm{E}$ is a serum lipoprotein (34.2 kDa). It is secreted by adrenals of the kidneys and macrophages but is mainly synthesized by liver. Apolipoprotein E plays a role in the metabolization of phospholipid and cholesterol. It is capable of transporting lipids in cells over interplay with receptors [6].

The $\beta A P P$ gene is associated with Alzheimer's disease in terms of hereditary predisposition. The $\beta$-Amyloid Precursor Protein gene encodes a single transmembrane including polypeptide (770 amino acids) [7]. $\beta$-Amyloid Precursor Protein is a member of the family of APP-like proteins. The BAPP is a single transmembrane protein. This protein has a 23 residue hydrophobic stretch and functions as an APP in the phospholipid bilayer of internal and external membranes [6]. BAPP pioneer protein is exposed to a number of endoproteolytic moieties. One of these is mediated by a putative membrane-associated a-secretase, which cleaves $\beta$ APP695 in the middle of the A $\beta$ peptide domain and liberates the extracellular $\mathrm{N}$-terminus of $\beta$ APP. The first divides $\beta$-Amyloid Precursor Protein 695 in the middle of the $A \beta$ peptide domain and rescues the extracellular $\mathrm{N}$-terminus of $\beta$-APP. The latter pathway includes consecutive cleavages by $\beta$ - and $\gamma$-secretases and creates 40/42 amino acid $A \beta$ peptide [7]. The extracellular domain of Amyloid Precursor Protein links to a series of proteoglycan molecules. This condition allows it to function as a regulator of cell-cell or cell-matrix interplays, cell expansion and synaptic flexibility. Amyloid Precursor Protein functions like a cell surface receptor [4].

Researchers detected PS1 gene and PS2 gene mutations in early onset familial AD in 1995. So far, nearly 160 mutations in PS1 and 10 mutations in PS2 genes are associated with familial AD [8]. The PS1 gene is transcribed at low levels in the non-neurological tissues and central nervous system. Presenilin 1 encodes a polytopic integral membrane protein [9].

The PS1 protein is located within intracellular membranes in the Golgi apparatus, the endoplasmic reticulum, the perinu- clear envelope and the intracytoplasmic vesicles [7]. PS2 is expressed in skeletal muscle, cardiac muscle, and pancreas. The topology of Presenilin 2 is analogous to that of Presenilin 1; however, multimeric protein complexes include $\beta$-catenin [9].

PS1 encodes 467 amino acid transmembrane proteins and PS2 encodes 448. Presenilin 1 and Presenilin 2 are subunits of $\gamma$-secretase. $\gamma$-secretase forms a spectrum of peptides (varying in length, $\geq A \beta 42$ and $\leq A \beta 40$ ), termed $A b$, which accumulates in the brains of Alzheimer's disease cases [8].

The presenilin gene mutations cause of familial autosomal dominant early-onset $A D$. Mutant presenilins can increase $A \beta$ production and conduce to AD progression. PS2 plays less of a role than PS1 [10]. PS1 mutations increase the production of $A \beta-42$ [6]. PS2 mutations are related to autosomal dominant early-onset $A D$ and late-onset $A D$. PSEN2 mutations have a wide series in the age of onset from $40-80$ ages [10].

The first PS1 mutation related to familial Alzheimer's disease was reported in 1995 [11-13]. Thenceforth, 120 types of PS1 mutation have been announced in 260 families around the world. All of PSEN1 mutations are missense and this condition gives increase to the substitution of a single amino acid. Just two splicing defect mutations have been announced [14, 15]. Moreover, the mutations are very often investigated in exon 5 "28 mutations", exon 7 "23 mutations", exon 8 "20 mutations". Intron mutation were also identified to be able to generate Alzheimer's disease [16].

Alzheimer's disease related with PS1 mutation was found in 18 families on codon 206 "Gly206Ala". The other mutations are "Met146Len" in 12 families, "Glu280Ala" in 12 families, "His163Arg" in 10 families, and "Pro264Leu" in 8 families. All of the PS1 mutations were identified to cause early onset Alzheimer's disease. The PS1 mutation on codon 318 "Glu318Gly" was determined in 6 families with sporadic Alzheimer's disease and 4 families with Familial Alzheimer's disease [16, 17]. This mutation is identified as a fractional pathogenetic factor. The Presenilin 2 gene was first identified on chromosome 1 and this gene has a total $62 \%$ being homologous to Presenilin 1 gene $[18,19]$.

\section{Materials and Methods}

In this study, cDNA of the Presenilin 2 gene, which has been cloned to the Smal restriction enzyme site of pcDNA3, was cut out by BamHI and Kpnl enzymes. The cDNA fragment was further inserted between the BamHI and Kpnl sites of the pBluescript II SK (+) vector.

XL-1 Blue E.coli cells were transformed with the vector and positive colonies on LB/Agar medium were selected for plasmid DNA isolation.

The transformation was confirmed by DNA sequence analysis. The cloned cDNA sequence was changed by the site-directed 
mutagenesis method to construct vectors carrying Ala252Thr and Pro334Arg mutations. The XL- 1 Blue cells were transformed by the mutant clones to obtain pure colonies. In the future, the necessary vectorial infrastructure has been provided in order to study the effects of mutations in cell culture studies.

\section{Examples of XL-1 Bacteria, DNA and RNA}

XL-1 Blue bacterium, pBluescript II sk (+) phagemid vector (Figure 1), pWhitescript vector were provided by Haliç University Molecular Biology and Genetics Department. The pcDNA3 vector carrying the PSEN2 cDNA (Promega) that was cloned into the Smal restriction enzyme cutting site (Figure 2 ) was provided by the Neurogenetic Laboratory of the Flanders Interuniversity Institute of Biotechnology (Antwerp University, Belgium) (Table 1).

\section{Primers}

Primer sequences used in the study for PCR and directed mutagenesis are given in Table 2.

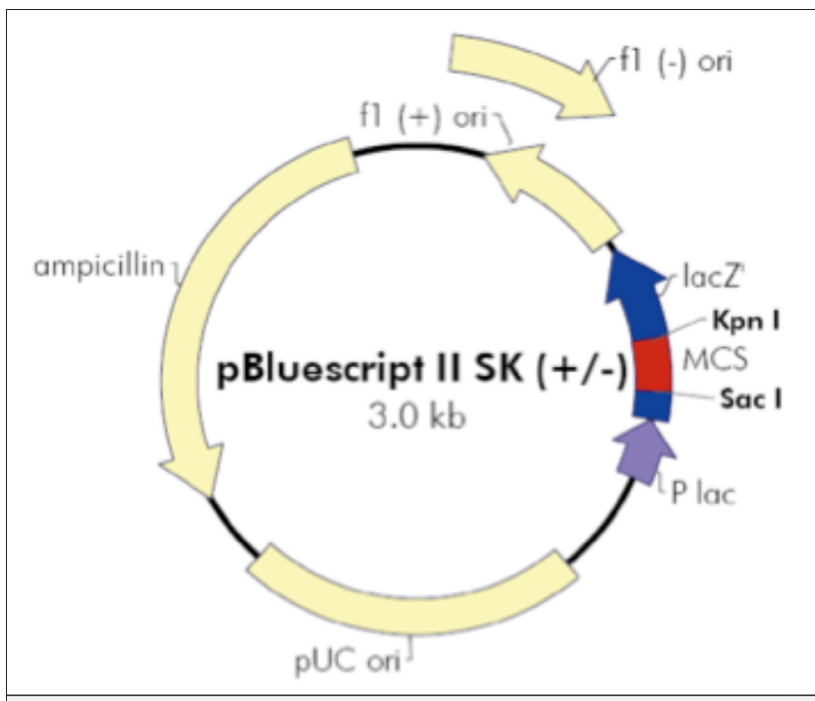

Figure 1. pBluescript II SK (+/-) Phagemids

\section{Used Chemicals}

All reagents used in this study (Table 3) Stratagene (USA), Roche (Germany), Fermentas (El) and the Eczacibasi (Turkey) are the products of the company. The chemicals and their contents are shown in Table 3.

\section{Cleavage of pBluescript II sk (+) Vector with BamHI and Kpnl Enzymes}

The PSEN2 cDNA from the Neurogenetics Laboratory of the University of Antwerp was cloned into the pcDNA3 vector. However, this vector leads to low transformation efficiency due to its size in bacterial transformation at a base size of 7306. For this reason, the PSEN2 cDNA sequence in pcDNA3 was extracted from this vector and cloned into the smaller pBluescript II sk (+) vector. Mutations that were desired to be generated on the coding region were generated by the directed mutagenesis method after cloning into the PSEN2 sequence pBluescript II sk (+) vector.

\section{Cutting the pcDNA3 Vector with BamHI and KpnI Restriction Enzymes}

$1 \mathrm{ng}$ pcDNA3 vector was cut with 10 units of BamHI restriction enzyme at $37^{\circ} \mathrm{C}$ for 3 hours. The reaction mixture consisted of $1 \mu \mathrm{l}$ pcDNA3 solution, $1.5 \mu \mathrm{l}$ reaction buffer solution, $0.2 \mu \mathrm{l}$ BamHl enzyme, and $17.3 \mu \mathrm{ddd}_{2} \mathrm{O}$. After cutting, the products were run on a $0.7 \%$ agarose gel at $150 \mathrm{~V}$ for $35 \mathrm{~min}$. The cut vector band was cut with agarose jelly bistur in UV light, and a $1.5 \mathrm{ml}$ eppendorf tube was placed. The isolated vector was dis-

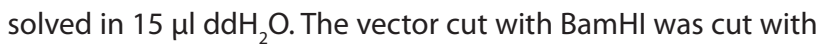
10 units of $\mathrm{Kpnl}$ restriction enzyme for 3 hours at $37^{\circ} \mathrm{C}$. The reaction solution was prepared by dissolving the vector solution in $15 \mu \mathrm{l}$ of ddH2O, $1 \mu$ l of Kpnl enzyme, $2 \mu$ reaction buffer solution, and $2 \mu \mathrm{l}$ of $\mathrm{dd}_{2} \mathrm{O}$. After cutting, the products were run on a $0.7 \%$ agarose gel at $150 \mathrm{~V}$ for $35 \mathrm{~min}$. The DNA band carrying the PSEN2 sequence was cut with agarose jelly bisturia in UV light and placed in a $1.5 \mathrm{~mL}$ eppendorf tube. The vector was isolated from the agarose gel using a plasmid isolation kit. The isolated vector was dissolved in $15 \mu \mathrm{ldd} \mathrm{H}_{2} \mathrm{O}$.

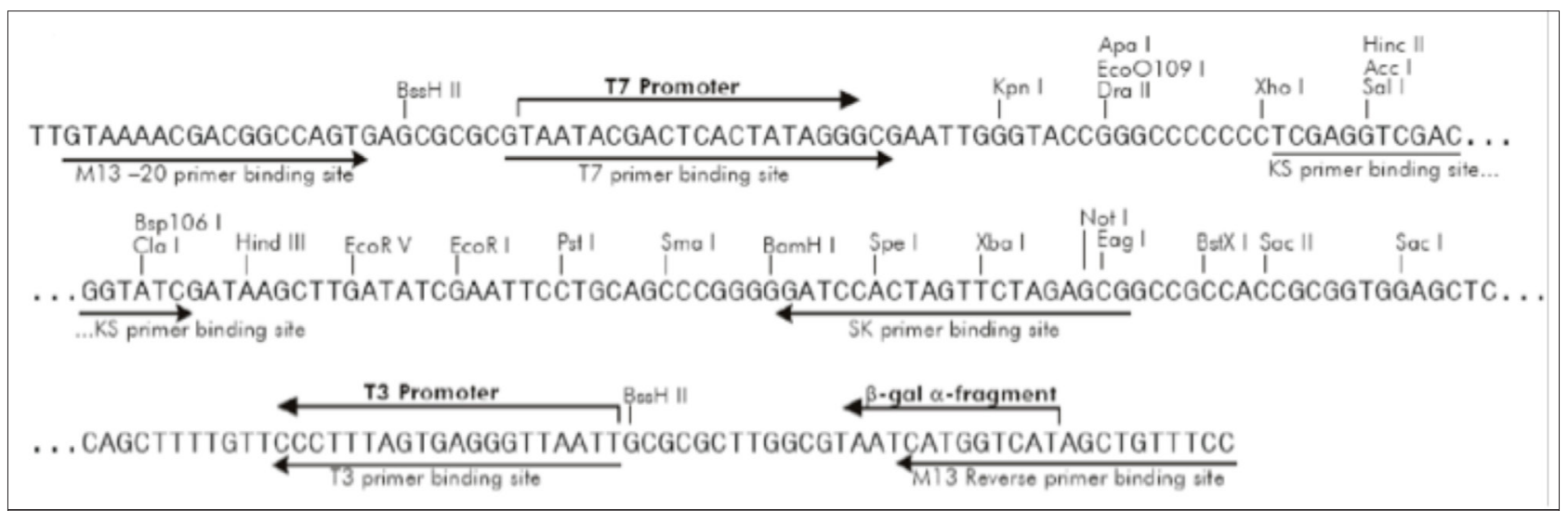

Figure 2. pBluescript II SK (+/-) Multiple Cloning Region (representing sequence 598-826) 


\section{Cleavage of pBluescript II sk (+) Vector with BamHI and Kpnl Enzymes}

$1 \mathrm{ng}$ pBluescript II sk (+) vector was cut with 10 unit of Bam$\mathrm{HI}$ restriction enzyme for 3 hours at $37^{\circ} \mathrm{C}$. The reaction mixture consisted of $1 \mu \mathrm{l}$ pBluescript II sk (+) solution, $1.5 \mu \mathrm{l}$ reaction buffer solution, $0.2 \mu \mathrm{l} \mathrm{BamHI}$ enzyme, and $17.3 \mu \mathrm{lddH_{2 }} \mathrm{O}$. After cutting, the products were run on $0.7 \%$ agarose gel at $150 \mathrm{~V}$ for $35 \mathrm{~min}$. The cut vector band was cut in UV light by agarose jelly bisturia and placed in a $1.5 \mathrm{~mL}$ eppendorf tube. The vector was isolated from the agarose gel using a plasmid isolation kit. The isolated vector was dissolved in $15 \mu \mathrm{lddH_{2 }}$ O. The vector cut with BamHI was cut with 10 units of Kpnl restriction enzyme at $37^{\circ} \mathrm{C}$ for 3 hours. The reaction solution was prepared by dissolving the vector solution in $15 \mu \mathrm{l}$ of $\mathrm{dd}_{2} \mathrm{O}, 1 \mu \mathrm{l}$ of Kpnl enzyme, $2 \mu \mathrm{l}$ of reaction buffer solution, and $2 \mu \mathrm{l}$ of $\mathrm{dd}_{2} \mathrm{O}$. The reaction solution was prepared by dissolving the vector solution in $15 \mu \mathrm{l}$ of $\mathrm{ddH}_{2} \mathrm{O}, 1 \mu \mathrm{l}$ of Kpnl enzyme, $2 \mu \mathrm{l}$ of the reaction buffer solution, and $2 \mu \mathrm{l}$ of $\mathrm{ddH}_{2} \mathrm{O}$. After cutting, the products were run on a $0.7 \%$ agarose gel at $150 \mathrm{~V}$ for $35 \mathrm{~min}$. The cut vector band was

Table 1. pBluescript II SK (+/-) Vector

\begin{tabular}{|c|c|}
\hline Feature & $\begin{array}{l}\text { Nucleotide } \\
\text { Position }\end{array}$ \\
\hline $\begin{array}{l}\text { The } f 1(+) \text { origin of ss-DNA replication } \\
\text { [pBluescript SK }(+)]\end{array}$ & $135-441$ \\
\hline $\begin{array}{l}\text { The f1 (-) origin of the ss-DNA replication } \\
\text { [pBluescript SK (-)] }\end{array}$ & $21-327$ \\
\hline $\begin{array}{l}\text { The } \beta \text {-galactosidase a-fragment coding } \\
\text { sequence (lacZ') }\end{array}$ & $460-816$ \\
\hline Multiple cloning sites & $653-760$ \\
\hline T7 promoter transcription initiator region & 643 \\
\hline T3 promoter transcription initiator region & 774 \\
\hline Lac promoter & $817-938$ \\
\hline pUC replication origin & $1158-1825$ \\
\hline Ampicillin resistant (bla) ORF & $1976-2833$ \\
\hline
\end{tabular}

cut in UV light by agarose jelly bisturia and placed in a $1.5 \mathrm{~mL}$ eppendorf tube. The vector was isolated from the agarose gel using a plasmid isolation kit. The isolated vector was dissolved in $15 \mu \mathrm{ldd \textrm {H } _ { 2 }} \mathrm{O}$.

\section{Cloning of PSEN2 cDNA Sequence into pBluescript II sk (+) Vector}

\section{Transformation of XI-1 Cells}

XL-1 Blue supercompetent E. coli cells were transformed with the pBluescript vector containing PSEN2. In this step, E. coli cells that were transformed with the vector without PSEN2 for control purposes and untransformed E. coli cells were sown. Each transformation was carried out separately in $15 \mathrm{ml}$ falcon tubes. Stock XL-1 Blue stocks stored at -80C were solved on ice. From the falcon tubes previously cooled on ice, the first tube held $100 \mu \mathrm{l} \mathrm{XL}-1$ Blue cell and $1 \mu \mathrm{l}$ pBluescript, the second tube held $100 \mu \mathrm{l} \mathrm{XL-1}$ Blue cell and $15 \mu \mathrm{l}$ PSEN2 pBluescript vector solution, and the third tube only held $100 \mu \mathrm{ILL}-1$ Blue cell. The tubes, which were stirred without heating on ice, were again placed on ice for 30 minutes. Then, after waiting 45 seconds in the water bath at $42^{\circ} \mathrm{C}$, they were put in the bucket immediately and stayed for 2 minutes.

The tubes were then incubated for 1 hour at $37^{\circ} \mathrm{C}$ with $900 \mu \mathrm{l}$ pre-warmed SOC medium at $37^{\circ} \mathrm{C}$. After the incubation, $200 \mu \mathrm{l}$ of each tube was incubated overnight at $37^{\circ} \mathrm{C}$ on solid agar medium containing ampicillin, IPTG, and X-Gal.

\section{Plasmid Isolation from XI-1 Transform Bacteria}

The selected colony on the agar plate was transferred with a sterile loop in a falcon tube to a $10 \mathrm{~mL}$ ampicillinous fluid containing LB. After 4 hours of incubation at $37^{\circ} \mathrm{C}$, the falcon tubes were centrifuged at $5000 \mathrm{~g}$ for 10 minutes at $4^{\circ} \mathrm{C}$. The DNA Isolation Mini Kit product was used for isolation. After centrifugation, the supernatant was discarded and a total of 4 $\mathrm{mL}$ of RNase and RNase suspensions was added to the pellet and the mixture was gently shaken. The matt white suspension was filtered through the filtered columns by adding lysis buffer and neutralization buffer into the tubing. The column was

Table 2. Primer sequences

\begin{tabular}{llll}
\hline Procedure & Primer & Sequence & Tm \\
\hline PCR & PS2CF1 & CTGAAGGAACCTGAGACAG & $52.2^{\circ} \mathrm{C}$ \\
\cline { 2 - 4 } Mutagenesis & PS2CF2 & GCAAGCTATTGGAGCTGAAG & $53.9^{\circ} \mathrm{C}$ \\
\hline & Ala252Thr_F & TACCTCCCAGAGTGGTCCACGTGGGTCATCCTGGGCG & $72.2^{\circ} \mathrm{C}$ \\
\hline & Pla252Thr_R & CGCCCAGGATGACCCACGTGGACCACTCTGGGAGGTA & $72.5^{\circ} \mathrm{C}$ \\
\cline { 2 - 4 } & Pro334Arg_F & GACAGTTTTGGGGAGCGTTCATACCCCGAAGTC & 65.8 ${ }^{\circ} \mathrm{C}$ \\
\hline
\end{tabular}


Table 3. Chemicals

\begin{tabular}{|c|c|c|}
\hline \multirow[t]{4}{*}{ Enzymes } & $\begin{array}{l}\text { DNA modifying } \\
\text { enzymes }\end{array}$ & T4 DNA Ligase, Alkaline phosphatase \\
\hline & Polymerases & $\begin{array}{l}\text { DNA polymerases (Pfu DNA polymerase, Taq DNA polymerase, Tgo DNA } \\
\text { Polymerase; Roche, Germany) }\end{array}$ \\
\hline & \multirow[t]{2}{*}{ Restriction enzymes } & BamHI Restriction Enzyme (Fermentas) \\
\hline & & Kpnl Restriction Enzyme [Roche, 3000U(10U/ $\mu \mathrm{l})$ ] \\
\hline \multirow[t]{2}{*}{ PCR chemicals } & dATP, dTTP, dGTP, dCTP & Fermentas (100 mM each) \\
\hline & Sterile water $(\mathrm{dH} 2 \mathrm{O})$ & Roche, Mannheim, Germany \\
\hline \multirow{6}{*}{$\begin{array}{l}\text { Gel electrophoresis } \\
\text { chemicals }\end{array}$} & 10XTBE Buffer & 1M Tris-HCl, 900 mM Boric Acid, 20 mM Na2EDTA \\
\hline & 6X Loading Buffer & $0.2 \%$ BPB, $0.2 \%$ xylene cyanol FF, 60 \% glycerol, 60 mM EDTA \\
\hline & Ethidium Bromide & $10 \mathrm{mg} / \mathrm{mL}$ \\
\hline & $1 \%$ agarose gel & $100 \mathrm{ml} 0.5 \times \mathrm{TBE}+1 \mathrm{gr}$ agarose \\
\hline & Agarose & Prona Agarose Basica Le \\
\hline & $1 \mathrm{~Kb}$ DNA Marker & Fermentas \\
\hline \multirow[t]{2}{*}{ DNA extraction } & Alcohol & 70\% Ethanol, Absolute Ethanol \\
\hline & TE buffer & 20 mM Tris (pH 8.0), 0.1 mM Na2EDTA (pH 8.0) \\
\hline \multirow[t]{2}{*}{ E. coli Broth } & LB Agar & $\begin{array}{l}7 \mathrm{~g} \mathrm{NaCl}, 7 \mathrm{~g} \text { tryptone, } 3.5 \mathrm{~g} \text { yeast extract, } 1 \mathrm{~L} \text { distilled water, tetracycline }(15 \mathrm{mg} / \\
\mathrm{mL}) \text {, ampicillin }(50 \mathrm{mg} / \mathrm{ml}), 100 \mathrm{ul} \text { IPTG }(10 \mathrm{mM}) \text {, 100ul X-Gal (2\%) }\end{array}$ \\
\hline & LB Broth & $\begin{array}{l}10 \mathrm{~g} \mathrm{NaCl}, 10 \mathrm{~g} \text { tryptone, } 5 \mathrm{~g} \text { yeast extract, } 1 \mathrm{~L} \text { distilled water, tetracycline }(15 \mathrm{mg} / \\
\mathrm{ml}) \text {, ampicillin }(50 \mathrm{mg} / \mathrm{mL})\end{array}$ \\
\hline
\end{tabular}

washed with a new falkon placed colon washing buffer so that the target plasmid external molecules were removed from the column.

The solution in the falcon tube contained the intended target plasmids. The resulting plasmids were precipitated with $3.6 \mathrm{~mL}$ of isopropanol at room temperature. Immediately after, centrifugation was carried out for 60 minutes at 13000 $\mathrm{g}$ at $4^{\circ} \mathrm{C}$. After centrifugation, the supernatant was carefully removed. The plasmids were centrifuged at $13000 \mathrm{~g}$ for 20 minutes with $3 \mathrm{ml}$ of $70 \%$ ethanol previously cooled at $4^{\circ} \mathrm{C}$. After centrifugation, the ethanol was removed and the pellet remaining in the bottom of the tubes was dried for about 10 minutes. $50 \mu \mathrm{l}$ TE buffer solution was added to pellet in each tube containing plasmid DNA. $2 \mu \mathrm{l}$ of the obtained DNA solution was run on a $0.7 \%$ agarose gel and the quality was checked.

\section{Sequence Analysis}

The PSEN2 CDNA sequence that was cloned and that was not cloned into the pBluescript vector was determined by DNA sequencing data analysis. $10 \mu$ of the resulting vector solution was submitted to MACROGEN (South Korea) for sequence anal- ysis along with $\mathrm{T} 3$ primers located on the 3 ' side and T7 primers located on the $5^{\prime}$ side of the pBluescript multiple cloning site. A sequence analysis was performed from both sides. The analysis results were evaluated using the Chromas Pro (Technelysium) program.

\section{Directed Mutation Creation on PSEN2 cDNA}

The QuikChange ${ }^{\circledR}$ XL Site-Directed Mutagenesis Kit (Stratagene) was used to generate Val89Leu and Ile439Val mutations on the PSEN2 CDNA. The directed mutagenesis reaction was performed with $5 \mu \mathrm{l}$ of the reaction buffer solution, $5 \mu \mathrm{l}$ of the pBluescript vector solution containing PSEN2, $2 \mu$ l of the linear primer, $2 \mu \mathrm{l}$ of the reverse primer, $1 \mu \mathrm{l}$ of the dNTP mixture, 3 $\mu \mathrm{l}$ of QuickSolution, $32 \mu \mathrm{l}$ of $\mathrm{ddH} 2 \mathrm{O}$, and $1 \mu \mathrm{l}$ of the PfuTurbo polymerase enzyme.

A reaction tube was prepared to control the directed mutagenesis reaction. Into this tube, pWhiteScript $(2 \mu \mathrm{l})$ and control primers (1.25 $\mu$ leach) were placed instead of pBlueScript and PSEN2 primers. These control primers translate the pWhiteScript sequence into the pBlueScript sequence by correcting the STOP codon mutation in the LacZ gene found in the pWhiteScript. 
Table 4. Directed mutagenesis conditions

\begin{tabular}{lccc}
\hline Segment & Cycle & Temperature & Time \\
\hline 1 & 1 & $95^{\circ} \mathrm{C}$ & $1 \mathrm{~min}$ \\
\hline 2 & 18 & $95^{\circ} \mathrm{C}$ & $50 \mathrm{sec}$ \\
\cline { 2 - 4 } & & $60^{\circ} \mathrm{C}$ & $50 \mathrm{seC}$ \\
\cline { 2 - 4 } & & $68^{\circ} \mathrm{C}$ & $6 \mathrm{~min}$ \\
\hline 3 & 1 & $68^{\circ} \mathrm{C}$ & $7 \mathrm{~min}$ \\
\hline
\end{tabular}

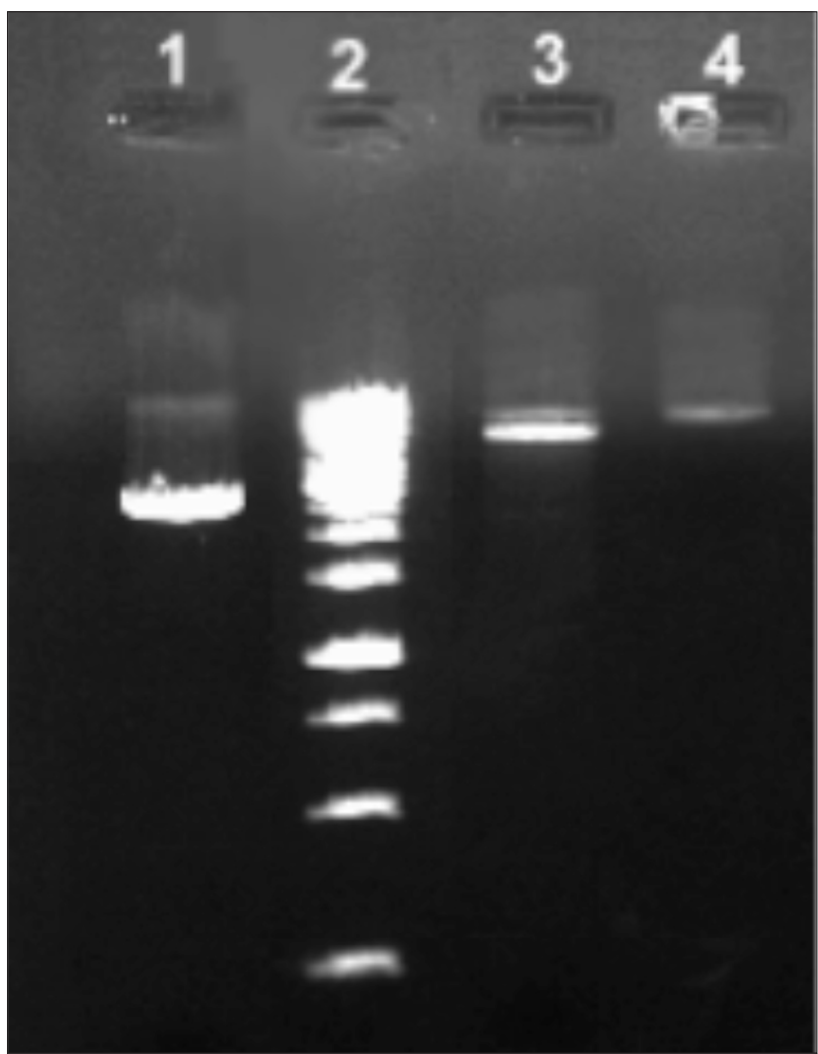

Figure 3. truncation of pcDNA3 and pBlueScript II sk (+) vectors with the BamHI restriction enzyme. 1) truncated pBlueScript II sk (+); 2) 1 kb Marker; 3) truncated pcDNA3, 4) untruncated pcDNA3

If the directed mutagenesis reaction is successfully applied, the E. coli cells transformed with this vector will form blue colonies instead of white. The prepared tubes were added to the polymerase chain reaction apparatus, and mutant chain synthesis was provided according to the conversion protocol given in Table 4.

The resulting solution obtained by mutagenesis was incubated at $37^{\circ} \mathrm{C}$ for 1 hour with the addition of $1 \mu$ (10 units) of Dpnl restriction enzyme. Dpnl identifies the 5'-Gm6ATC-3 'sequences on the methylated DNA and cuts A-T smoothly. Thus, while the methylated template DNA molecule was fragmented, the newly synthesized mutant DNA chain remained a single frag- ment. XL-1 Blue cells were transformed with vectors truncated with Dpnl and incubated overnight with plates containing ampicillin, IPTG, and X-Gal.

\section{Mutant Plasmid Isolation from XI-1 Transform Bacteria and DNA Sequence Analysis}

The plasmid was isolated from the transformed bacterial colonies suspected of carrying the mutation and the $0.7 \%$ agarose gel was checked for quality. $10 \mu \mathrm{L}$ of the mutant plasmid was sent to the MACROGEN (South Korea) company along with the primers surrounding the mutation, and the sequence from both sides of the mutated region. Analysis results were evaluated using the Chromas Pro (Technelysium) program.

\section{Results}

Any mutation in the PSEN1, PSEN2, APP and APOE genes can cause early-onset AD. While some of the mutations that occur in the field are unrelated (do not show any protein increase causing the disease), many of them are meaningful mutations (which cause disease or altered protein production). The allele in the APOE gene is a risk factor for the disease. The A 342 peptide, which is formed by the secretase enzymes of amyloid-beta peptides due to incorrect clippings, causes early onset AD. Although the total amount of $A \beta$ in the mutations occurring in the coding regions of the PSEN2 gene does not change, it is argued that $A \beta 42$ ratio is caused by the increase.

However, no increase in $A \beta 42$ was observed in studies performed in cell cultures on point mutations. This suggests that PSEN2 mutations may lead to the disease with different mechanisms. It is seen that experimental studies in this subject are inadequate in the literature. In order to understand the role of PSEN2 mutations in the mechanism of the disease, cell cultures carrying the PSEN2 mutation are needed. Our study was aimed at cloning the PSEN2 gene in our laboratory and create vectors with different mutations by directed mutagenesis. As a result of the experiments, the PSEN2 cDNA was cloned between the BamHI (Figure 3) and Kpnl (Figure 4) cut-off points of the pBluescript II sk (+) vector (Figure 5, 6).

Continuous mutations of Ala252Thr (252. base Alanine $\rightarrow$ Threonine mutation on cDNA) (Figure 7) with Pro334Arg (334 base Proline $\rightarrow$ Arginine mutation on CDNA) (Figure 8 ) were successfully generated on the inset PSEN2 cDNA. The vector containing the insert is purified and stored as a stock solution at $-80^{\circ} \mathrm{C}$ for further work. In addition, XL-1 Blue E. coli cells bearing this vector were also made competitively and stored at $-80^{\circ} \mathrm{C}$. These two consecutive meaningful mutations can be subsequently used for expression analysis in eukaryotic cell cultures. It is possible to determine whether there is any increase in $A \beta 42$ level as a result of protein expression, and the effect on this early onset $A D$ can be discussed. 


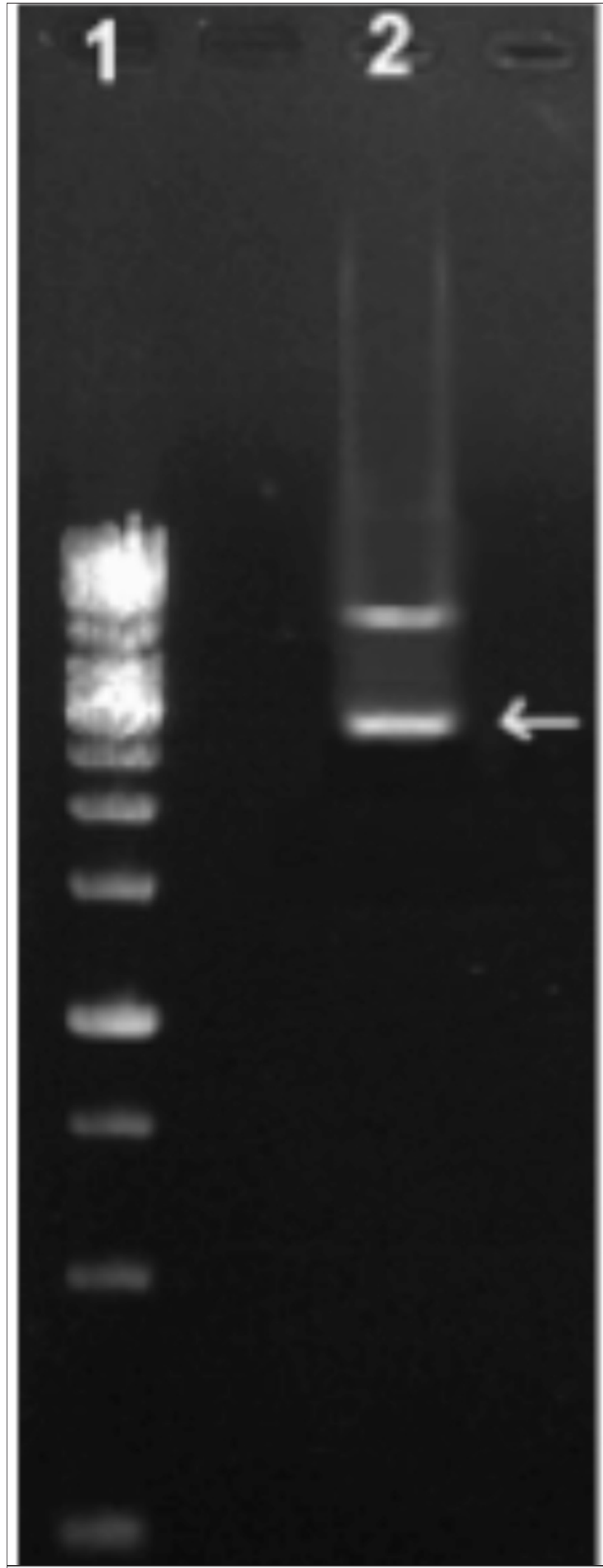

Figure 4. After cleavage with BamHI, the Kpnl was digested with restriction enzyme twice pcDNA3 vector. 1) 1 kb Marker, 2) truncated pcDNA3 vector, sub-band carrying PSEN2 insert

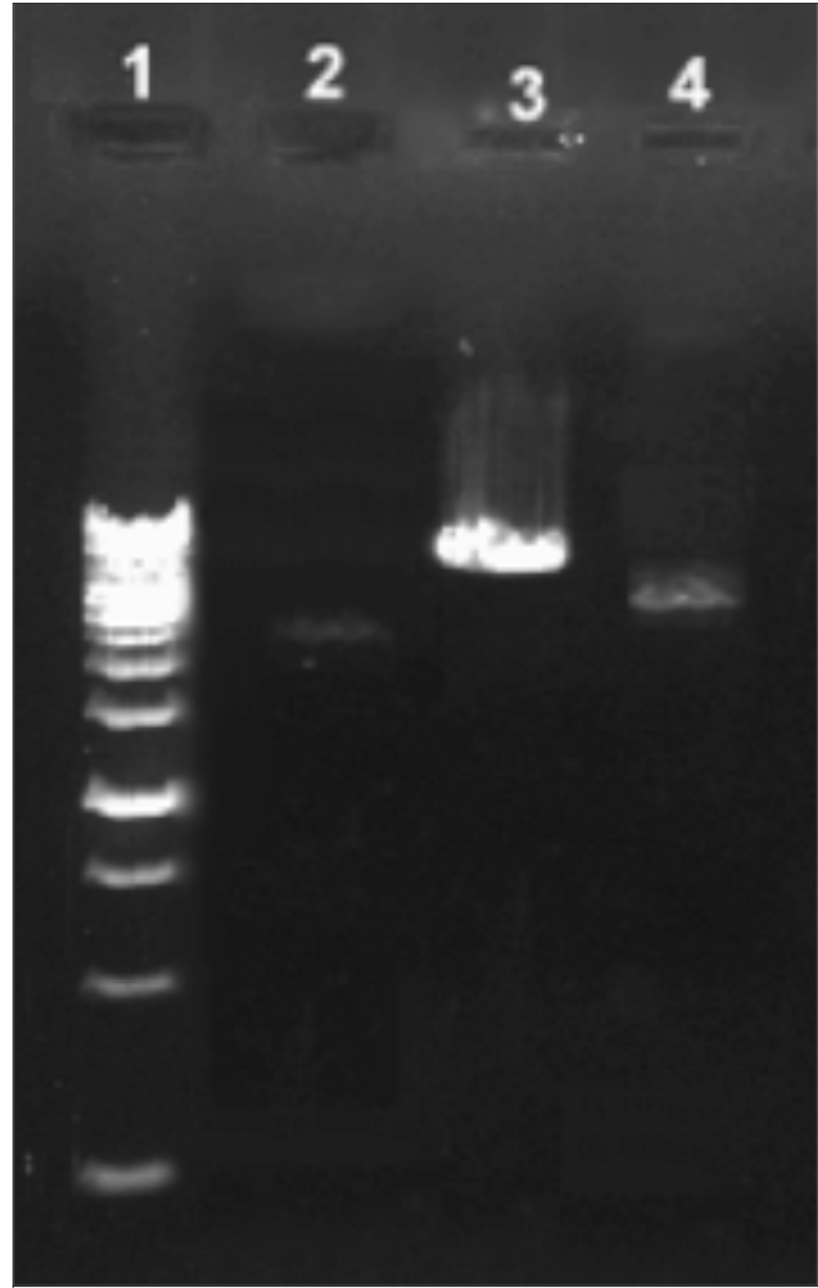

Figure 5. Cloning of the PSEN2 insert into the pBlueScript II sk (+) vector

\section{Conclusion}

Alzheimer's disease isn't a normal component of the aging process although it imitates alterations in the brain due to aging in some respects. Cell death occurs in the brain as a result of abnormal protein formations, called senile plaques, and nerve fiber bundles. The risk of Alzheimer's disease increases with age, and late-onset $\mathrm{AH}$ starting after the age of 65 is not considered to be hereditary. PS1, PS2, and APP gene mutations constitute abnormal proteins that cause Alzheimer's disease. It is described in other genes and they carry a risk of the formation of late-onset Alzheimer's, however not directly induced by Alzheimer disease.

Alzheimer's disease is categorized in a late-onset, an early-onset, familial type, sporadic type which indicates about $95 \%$ of the patients [20]. The genetic factors of early-onset Alzheimer's disease are heterogeneous. APOE4 allele is a changing factor for age of onset in early-onset Alzheimer's disease induced by the PS2 and APP mutations [21]. PS1-PS2 and APP mutations use amyloidosis in Familial Alzheimer's disease patients 


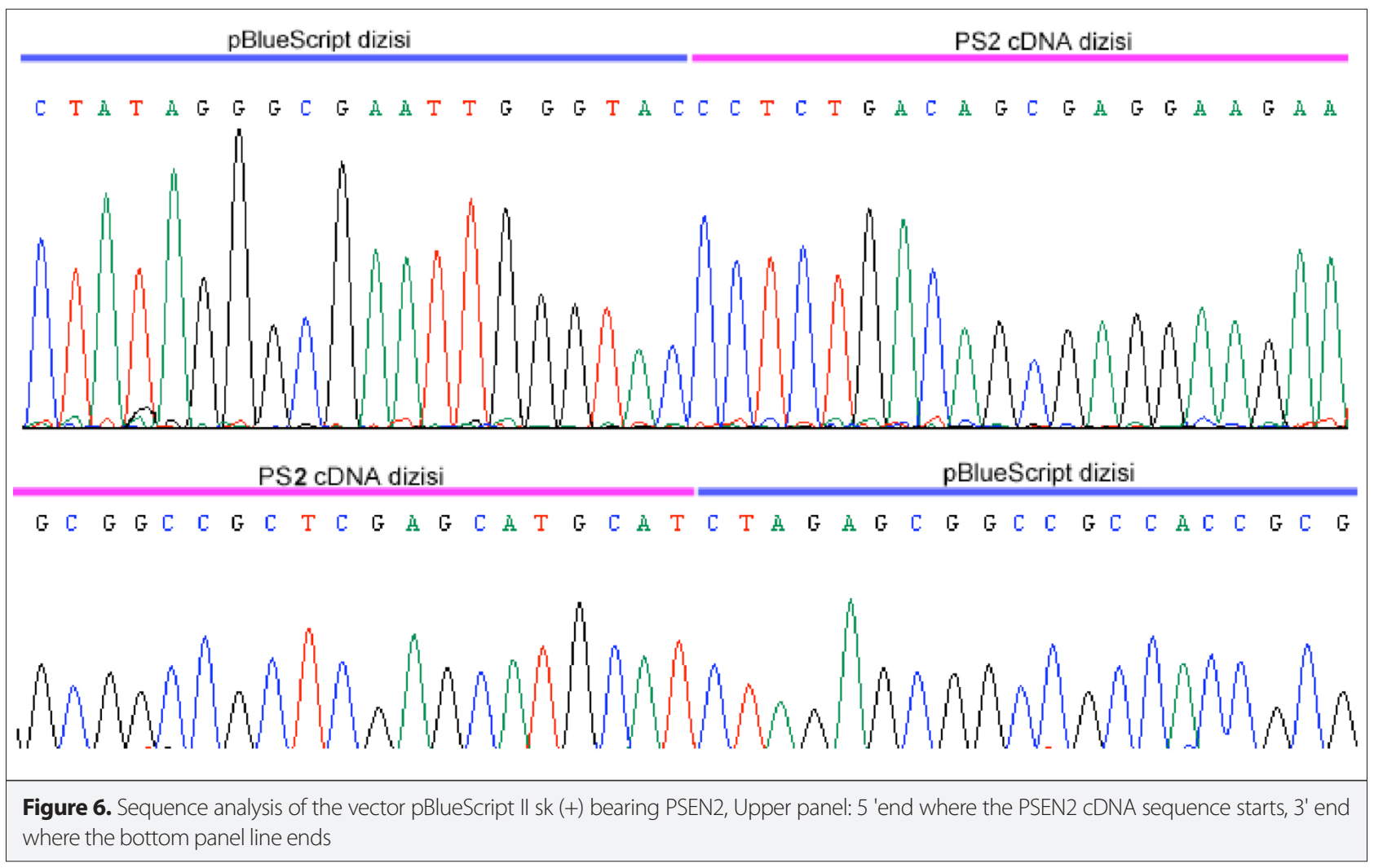

T A

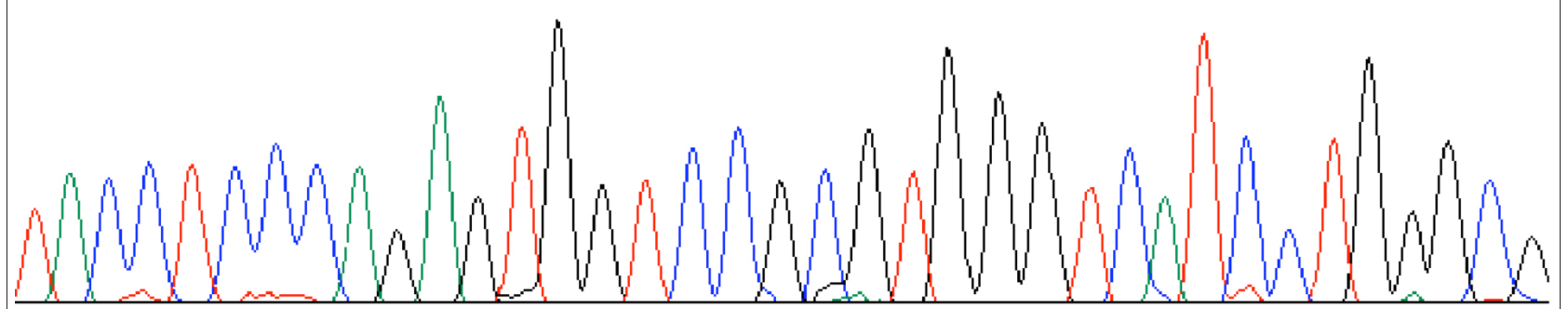

$T$ A

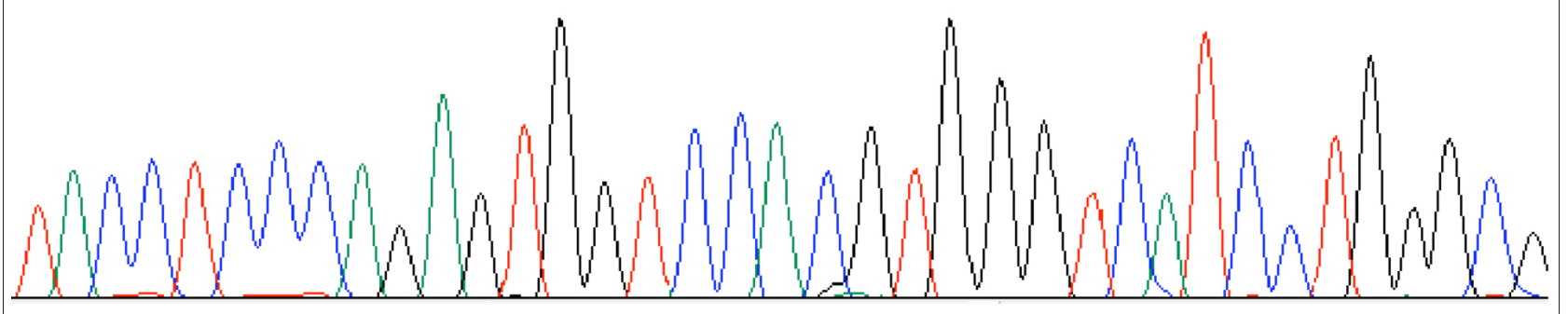

Figure 7. Ala252Thr mutation generated on the PSEN2 cDNA sequence. Top panel wild-type array, bottom panel mutant array, arrow mutation location

through modifying the brain metabolism of $A \beta$ peptides that support the production of pathogenic aggregates [22]. PS1 gene mutations were contributed to $18-55 \%$ of early-onset familial Alzheimer's disease cases [21].
150 RNA samples from the entorhinal and auditory cortex and the hippocampal areas of Alzheimer's disease patients and control groups were analyzed using RT- PCR in the study performed by Delabio et al. [23]. They didn't observe differences between 


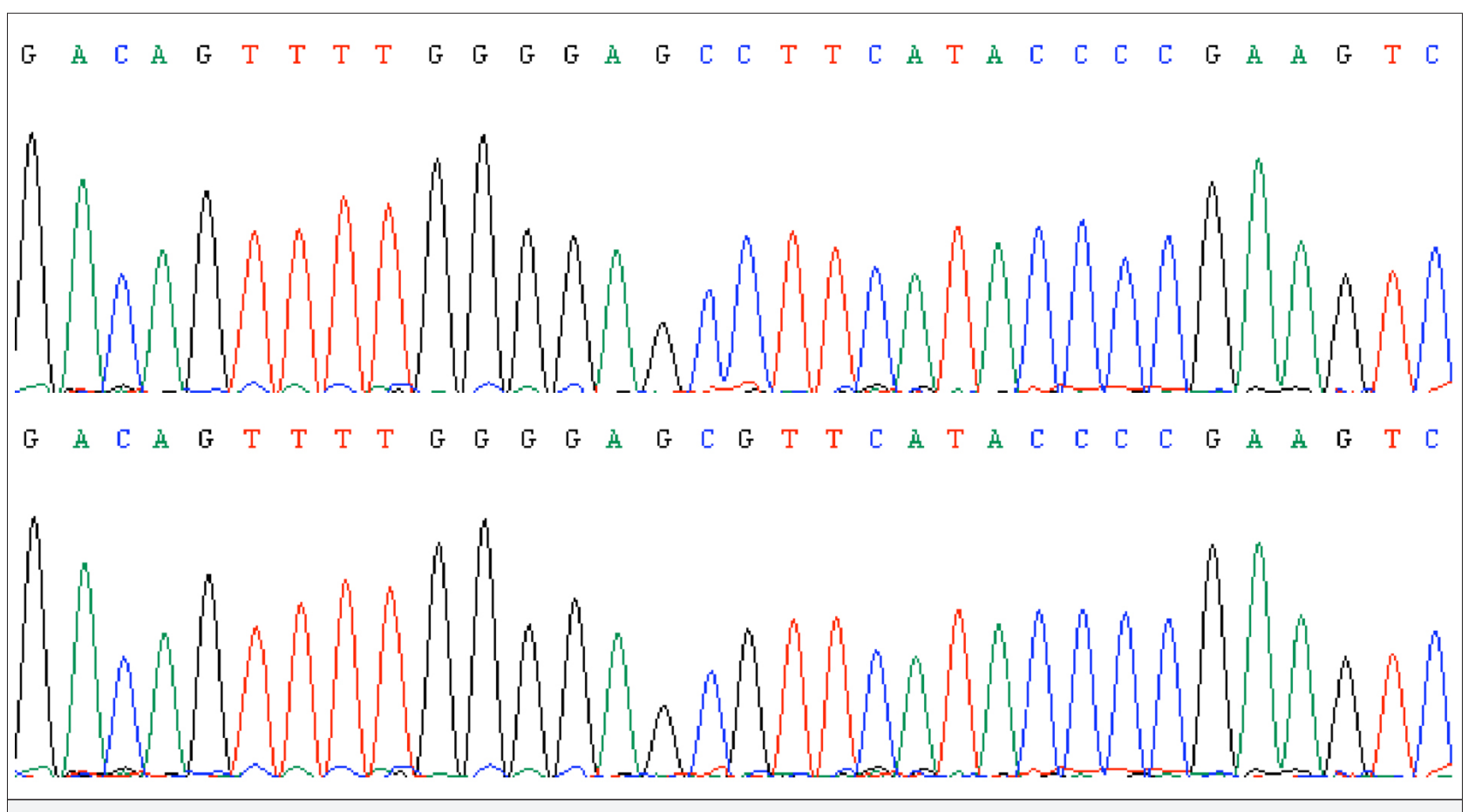

Figure 8. Pro334Arg mutation generated on the PSEN2 cDNA sequence. Top panel wild-type array, bottom panel mutant array, arrow mutation location

two groups in PS1 expression. Presenilin 2 gene was remarkably downregulated in the auditory cortex Alzheimer's disease patients when compared to other brain regions of the Alzheimer's disease patients and to the control group. Changing in PSEN2 expression may be a risk factor for Alzheimer's disease [23].

Nowadays, for the purpose of research, gene tests of the PS1 gene, the PS2 gene and the APP are performed. In this thesis study, significant mutations of Pro334Arg (334 base Proline $\rightarrow$ Arginine mutation on CDNA) and Ala252Thr (252 base region Alanine $\rightarrow$ Threonine mutation on CDNA) on PSEN2 cDNA were created, and expression analysis in eukaryotic cell cultures was made possible.

We have studied 2 samples of early-onset Alzheimer's disease patients and detected 10 novel missense mutations, 1 novel indel, and 1 novel genomic deletion in PS1 and 1 novel missense mutation in PS2.

Lanoiselée et al. [24] performed sequencing of the Presenilin 1, Presenilin 2, and Amyloid Precursor Protein genes in 129 sporadic cases and early-onset Alzheimer's disease families. Mutations were detected in 18 sporadic cases and 170 early-onset Alzheimer's disease (EOAD) families. c.850A>G, p.(Arg284Gly) (novel PSEN2 mutation) and p.(Thr122Pro) were identified. PS1 c.236C>T, p.(Ala79Val) substitution is recently considered as pathogenic and directs to an increase in $A \beta 42-A \beta 40$ ratios in cell cultures. This variant (several families with late-onset Alzheimer's disease) appears to be related to a later onset compared to the other PS1 variants. Presenilin 2 c.211T>C, p.(Arg71Trp) variant was firstly found in late-onset Alzheimer's disease patients. Lanoiselée et al. [24] noticed this variant is nonpathogenic in 2 early-onset Alzheimer's disease families. Their evidence propose that a non-negligible fraction of PS1 mutations occurs de novo while PSEN1 mutational screening is recently applied in familial cases only.

The accumulation of amyloid fibrils creates $A \beta$ protein as senile plaques in the brain are a pathological feature of $A D$. The correlation of soluble $A \beta$ oligomers $\left(A \beta^{*} 56\right)$ to dementia is stronger than the correlation between fibrils and dementia, which indicates that $A \beta$ oligomers may be the prime toxic types [25].

According to Krüger et al. [26], PS1, PS2 and APP gene mutations have been observed as inducing a ratio of early-onset Alzheimer disease patients. In order to evaluate the role of these genes in a clinical series of Finnish eoAD and FTLD patients. Krüger et al. [26] exon16-exon 17 of the APP gene sequenced and PS1 and PS2 genes coding regions sequenced in eoAD (140 patients) and FTLD (66 patients). Krüger et al. [26] did not define pathogenic mutations in the cohort. The E318G variant was identified with analogous frequencies in the patients with eoAD and FTLD and healthy controls, for this reason, they observed no association among E318G and early-onset Alzheimer's disease. Also, the PSEN2 R71W variant appears to be non-pathogenic, due to it being present in healthy control subjects. PS1, PS2, and APP genes showed no pathogenic mutations in eoAD and FTLD patients even when $40 \%$ of the patients were familial ones [26].

As a result, a step has been taken to determine the effect on early-onset $A D$ as it can be determined whether there is any 
increase in $A \beta 42$ in the protein level. Oligomerization and the structure mechanism of $A \beta$ oligomers are very important for growing efficient therapeutics.

Lindquist et al. [27] presented a patient with neuropathologically approved early-onset AD described by deep language corruption. The case was heterozygous for a novel missense mutation in exon 11 of the PS2 gene leadingto a foreboded amino acid substitution from valine to methionine in position 393. In vitro expression of PSEN2 V393M cDNA didn't result in detectable enhancing of the secreted $A \beta 42 / 40$ peptide rate. The mutation wasn't detected in 384 control subjects. It has been determined that amino acid substitution between methionine and valine is a conserved residue at position 393 in heterozygous patients for the new missense mutations in PSEN2 gene in exon 11 [27].

Neuropathology and the clinical process of sporadic Alzheimer's disease and familial Alzheimer's disease are extremely identifiable, and FAD patients compose a unique population in which to conduct treatment and especially interception trials with new pharmaceutical entities. Our study suggests that in the future, the role of PSEN mutations on cellular phenotypes and understanding of molecular mechanisms will shed light on the potential effects of presenilin mutations on therapeutic strategies targeting the Amyloid beta peptide.

PSEN1 mutations are usually more related to an earlier onset of the disease than PSEN2 mutations even when they consist of homologous residues. Walker et al. [28] guessed that PSEN2 FAD mutations would have a impressive effect on the $A \beta 42 / 40$ ratio so that have an observable effect on $A \beta$ levels in the presence of normal PSEN1 alleles. To trial this hypothesis they expressed PSEN2 and PSEN1 Familial Alzheimer's disease mutant arrangements in fibroblasts derived from PSEN1 -/- mice and PSEN2 -/- mice, therefore the mutant presenilin protein was the only resource of presenilin available in the cells [28].

Their functional analyses of putative PSEN2 FAD mutations indicated that M239V, M239l, T122P, and N141I meaningfully increased $A \beta-42$ levels and $A \beta$ 42-40 ratio as expected for FAD mutations. These mutations also produce a significant reduction in $A \beta-40$ levels. R62H, S130L, V148I, and D439A have no substantial impact on either $A \beta 40 / 42$ levels or $A \beta 42 / 40$ ratio [28].

Tomita et al. [29] showed cDNAs for wild-type PSEN2 and PSEN2 Volga German mutation (N141I) in culture cells and subsequently investigated the metabolism of the transfected proteins and their impact on the C-terminal features of excreted $\mathrm{A} \beta$ protein. This mutation (N141I) didn't induce any substantial change in the metabolism of PSEN2 [29].

COS-1 cells two times transfected with cDNAs for N141I mutant PSEN2 and human $\beta$-APP or a C-end fragment, also mouse Neuro2a cells transfected with N141I mutant PS2 alone, secreted 1.5- to 10-fold more $A \beta 42-43$ compared with those express- ing the wild-type PSEN2. Therefore, N141I mutation linked to familial Alzheimer's disease modifies the metabolism of $A \beta$ $\beta A P P$ to encourage the production the form of $A \beta$ that easily deposits in amyloid plaques [29].

Following studies are required to explain the mechanisms responsible for the effects of PS mutations on $A \beta$ production and the progression of AD. Additionally, the available results ensure strong assistance that the formation and deposition of $A \beta$ 42/43 plays a critical pathogenetic role in Alzheimer's disease.

Peer-review: Externally peer-reviewed.

Acknowledgements: The authors are grateful to Christine Van Broeckhoven and Marc Cruts (VIB-UAntwerp Center for Molecular Neurology) for providing PCDNA3 vector carrying PSEN2 CDNA. This study is funded by Halic Universtiy Research Fund.

Conflict of Interest: The authors have no conflicts of interest to declare.

Financial Disclosure: The authors declared that this study has received no financial support.

\section{References}

1. A Kumar, S. A. Ekavali, "A review on Alzheimer's disease pathophysiology and its management: an update", Pharmacol Rep, vol. 67, no. 2, pp. 195-203, 2015.

2. J. Guo, J. Cheng, B. J. North, W. Wei, "Functional analyses of major cancer-related signaling pathways in Alzheimer's disease etiology", Biochimica et Biophysica Acta (BBA) - Reviews on Cancer, vol. 1868, no. 2, pp. 341-358, 2017.

3. P. A. Defina, R. S. Moser, M. Glenn, J. D. Lichtenstein, J Fellus, "Alzheimer's Disease Clinical and Research Update for Health Care Practitioners", J Aging Res, 2013.

4. S. Parvathy, D. J. Buxbaum, "Molecular Genetics of Alzheimer Disease", Neuropsychopharmacology: The Fifth Generation of Progress, pp. 1199-1213, 2002.

5. L. Crews, E. Masliah, "Molecular mechanisms of neurodegeneration in Alzheimer's disease", Human Molecular Genetics, vol. 19, no. R1, pp. 12-20, 2010.

6. M. B. Yokes, "Molecular genetics of Alzheimer's Disease", J Cell Mol Biol, vol. 6, no. 2, pp. 73-97, 2007.

7. P. H. St George-Hyslop, A. Petit, "Molecular biology and genetics of Alzheimer's disease", Comptes Rendus Biologies, vol. 328, no. 2, pp. 119-130, 2004.

8. M. Plečkaitytè, "Alzheimer's disease: a molecular mechanism, new hypotheses, and therapeutic strategies", Medicina, vol. 46, no. 1, 2010.

9. P. H. St George-Hyslop. "Molecular Genetics of Alzheimer's Disease", Biol Psychiatry, vol. 47, no. 3, pp. 183-199, 2000.

10. Y. Cai, S. S. An, S. Kim, "Mutations in presenilin 2 and its implications in Alzheimer's disease and other dementiaassociated disorders", Clin Interv Aging, vol. 10, pp. 1163-1172, 2015.

11. G. D. Schellenberg, T. D. Bird, E. M. Wijsman, H. T. Orr, L. Anderson, E. Nemens, J. A. White, L. Bonnycastle, J. L. Weber, M. E. Alonso, H. Potter, L. L. Heston, G. M. Martin, "Genetic linkage evidence for a familial Alzheimer's disease locus on chromosome 14", Science, vol. 258, pp. 668-671, 1992. 
12. D. Campion, J. M. Flaman, A. Brice, D. Hannequin, C. Martin, V. Moreau, F. Charbonnier, O. Didierjean, S. Tardieu, C. Penet, M. Puel, F. Pasquier, F. Le Doze, G. Bellis, A. Calenda, R. Heilig, M. Martinez, J. Mallet, M. Bellis, F. C. Darpoux, Y. Agid, T. Frebourg, "Mutations of the presenilin I gene in families with early-onset Alzheimer's disease", Hum Mol Genet, vol. 4, no. 12, pp. 373- 377, 1995.

13. R. F. Clark, M. Cruts, K. M. Korenblat, C. He, C. Talbot, C. Van Broeckhoven, A. M. Goate, "A yeast artificial chromosome contig from human chromosome 14q24 spanning the Alzheimer's disease locus AD3", Hum Mol Genet, vol. 4, no. 8, pp. 1347-1354, 1995.

14. J. B. Kwok, K. Taddei, M. Hallupp, C. Fisher, W. S. Brooks, G. A. Broe, J. Hardy, M. J. Fulham, G. A. Nicholson, R. Stell, P. H. St George Hyslop, P. E. Fraser, B. Kakulas, R. Clarnette, N. Relkin, S. E. Gandy, P. R. Schofield, R. N. Martins, "Two novel (M233T and R278T) presenilin-1 mutations in early-onset Alzheimer's disease pedigrees and preliminary evidence for association of presenilin-1 mutations with a novel phenotype", Neuroreport, vol. 8, no. 6, pp. 1537-1542, 1997.

15. C. Tysoe, D. Galinsky, D. Robinson, C. Brayne, F. A. Huppert, T. Dening, E. S. Paykel, D. F. Easton, D. C. Rubinsztein, "Apo E and Apo $\mathrm{Cl}$ loci are associated with dementia in younger but not older late-onset cases", Dement Geriatr Cogn Disord, vol. 9, no. 4, pp. 19119-19118, 1998.

16. N. Suzuki, T. T. Cheung, X. D. Cai, A. Odaka, L. Otvos, C. Eckman, T. E. Golde, S. G. Younkin, "An increased percentage of long amyloid $\beta$ protein secreted by familial amyloid $\beta$ protein precursor $(\beta$ APP717) mutants", Science, vol. 264, pp.1336-1340, 1994.

17. K. Taddei, C. Fisher, S. M. Laws, G. Martins, A. Paton, R. M. Clarnette, C. Chung, W. S. Brooks, J. Hallmayer, J. Miklossy, N. Relkin, P. H. St George-Hyslop, S. E. Gandy, R. N.Martins, "Association between presenilin-1 Glu318Gly mutation and familial Alzheimer's disease in the Australian population", Mol Psychiatry, vol. 7, no. 7, pp. 776781, 2002.

18. E. Levy-Lahad, W. Wasco, P. Poorkaj, D. M. Romano, J. Oshima, W. H. Pettingell, C. E. Yu, P. D. Jondro, S. D. Schmidt, K. Wang, A. C. Crowley, Y. Hui Fu, S. Y. Guenette, D. Galas, E. Nemens, E. M. Wijsman, T. D. Bird, G. D. Schellenberg, R. E. Tanzi, "Candidate gene for the chromosome 1 familial Alzheimer's disease locus", Science, vol. 269, pp. 973-977, 1995.

19. E. I. Rogaev, R. Sherrington, E. A. Rogaeva, G. Levesque, M. Ikeda, Y. Liang, H. Chi, C. Lin, K. Holman, T. Tsuda, L. Mar, S. Sorbi, B. Nacmias, S. Piacentini, L. Amaducci, I. Chumakov, D. Cohen, L. Lannfelt, P. E. Fraser, J. M. Rommens, P. H. Hyslop-St George, "Familial Alzheimer's disease in kindreds with missense mutations in a gene on chromosome 1 related to the Alzheimer's disease type 3 gene", Nature, vol. 376, no. 6543, pp. 775-778, 1995.

20. H. J. Birnbaum, D. Wanner, A. F. Gietl, A. Saake, T. M. Kündig, C. Hock, R. M. Nitsch, C. Tackenberg. “Oxidative stress and altered mitochondrial protein expression in the absence of amyloid- $\beta$ and tau pathology in iPSC-derived neurons from sporadic Alzheimer>s disease patients", Stem Cell Res, vol. 27, pp. 121-130, 2018.
21. C. Zekanowski, M. Styczyńska, B. Pepłońska, T. Gabryelewicz, D. Religa, J. Ilkowski, B. Kijanowska-Haładyna, S. Kotapka-Minc, S. Mikkelsen, A. Pfeffer, A. Barczak, E. Łuczywek, B. Wasiak, M. Chodakowska-Zebrowska, K. Gustaw, J. Łaczkowski, T. Sobów, J. Kuźnicki, M. Barcikowska, "Mutations in presenilin 1, presenilin 2 and amyloid precursor protein genes in patients with early-onset Alzheimer's disease in Poland", Experimental Neurology, vol. 184, no. 2, pp. 991-996, 2003.

22. S. Weggen, D. Beher, "Molecular consequences of amyloid precursor protein and presenilin mutations causing autosomal-dominant Alzheimer's disease", Alzheimer's Res Ther, vol. 4, no. 2, p. 9, 2012.

23. R. Delabio, L. Rasmussen, I. Mizumoto, G. A. Viani, E. Chen, J. Villares, I. B. Costa, G. Turecki, S. A Linde, M. C. Smith, S. L. Payão, “PSEN1 and PSEN2 Gene Expression in Alzheimer's disease Brain: A New Approach", J Alzheimers Dis, vol. 42, no. 3, pp. 757-760, 2014.

24. H. M. Lanoiselée, G. Nicolas, D. Wallon, A. Rovelet-Lecrux, M. Lacour, S. Rousseau, A. C. Richard, F. Pasquier, A. Rollin-Sillaire, O. Martinaud, M. Quillard-Muraine, V. de la Sayette, C. Boutoleau-Bretonniere, F. Etcharry-Bouyx, V. Chauviré, M. Sarazin, I. le Ber, S. Epelbaum, T. Jonveaux, O. Rouaud, M. Ceccaldi, O. Félician, O. Godefroy, M. Formaglio, B. Croisile, S. Auriacombe, L. Chamard, J. L. Vincent, M. Sauvée, C. Marelli-Tosi, A. Gabelle, C. Ozsancak, J. Pariente, C. Paquet, D. Hannequin, D. Campion, "APP, PSEN1, and PSEN2 mutations in early-onset Alzheimer disease: A genetic screening study of familial and sporadic cases", PLoS Med, vol. 14, no. 3, p. e1002270, 2017.

25. S. Ngo, Z. Guo, "Key residues for the oligomerization of A 342 protein in Alzheimer's disease", Biochem Biophys Res Commun, vol. 414, no. 3, pp. 512-516, 2011.

26. J. Krüger, V. Moilanen, K. Majamaa, A. M. Remes, "Molecular Genetic Analysis of the APP, PSEN1, and PSEN2 Genes in Finnish Patients With Early-onset Alzheimer Disease and Frontotemporal Lobar Degeneration", Alzheimer Dis Assoc Disord, vol. 26, no. 3, pp. 272276, 2012.

27. S. G. Lindquist, L. Hasholt, J. M. Bahl, N. H. Heegaard, B. B. Andersen, A. Nørremølle, J. Stokholm, M. Schwartz, M. Batbayli, H. Laursen, R. Pardossi-Piquard, F. Chen, P. St George-Hyslop, G. Waldemar, J. E. Nielsen "A novel presenilin 2 mutation (V393M) in early-onset dementia with profound language impairment", Eur J Neurol, vol. 15, no. 10, pp. 1135-1139, 2008.

28. E. S. Walker, M. Martinez, A. L. Brunkan, A. Goate, "Presenilin 2 familial Alzheimer's disease mutations result in partial loss of function and dramatic changes in Ab 42/40 ratios. J Neurochem, vol.92, no. 2, 294-301. 2005;

29. T. Tomita, K. Maruyama, T. C. Saido, H. Kume, K. Shinozaki, S. Tokuhiro, A. Capell, J. Walter, J. Grünberg, C. Haass, T. Iwatsubo, K. Obata K, "The presenilin 2 mutation (N141I) linked to familial Alzheimer disease (Volga German families) increases the secretion of amyloid beta protein ending at the 42 nd (or 43rd) residue", Proc Natl Acad Sci USA, vol. 94, no. 5. 2025-2030, 1997. 